\title{
Development of Learning Material of Biotechnology Topic Based on STEAM-LW Approach for Secondary School in Coastal Area
}

\author{
Anjar Putro Utomo ${ }^{1}$, Ika Lia Novenda ${ }^{2}$, Aris Singgih Budiarso ${ }^{1}$, Erlia Narulita ${ }^{1^{*}}$ \\ ${ }^{1}$ Study Program of Science Education, University of Jember, Jember, Indonesi 68121 \\ ${ }^{2}$ Study Program of Biology Education, University of Jember, Jember, Indonesia 68121
}

\begin{abstract}
*Corresponding Author: Erlia Narulita, Study Program of Science Education, University of Jember, Jember, 68121, Indonesia.
\end{abstract}

\begin{abstract}
The purpose of this study was to develop learning material based on STEAM-LW approach in the Biotechnology subject of Grade IX students in coastal area. This research referred to R2D2 model and it used six validators to assess the quality and 72 students to test the prototype. Questionnaire of student and teacher, validator sheets, and questionnaires of the legibility and difficulty level were used. The result showed that learning material based on STEAM-LW has been strong valid of $87.50 \%$ score and can be used in learning process directly. Whereas the legibility level and student's response questionnaires exhibited that students gave positive response of $86.61 \%$ and $91.74 \%$, respectively. These results indicated that the learning materials based on STEAM-LW not only exceeded the validation process, but also it had a comprehensive biotechnology subject that satisfy the coastal area's student needs. In summarize, the developed-learning material based on STEAM-LW approach in the biotechnology subject is strong recommended for using in secondary school of coastal area.
\end{abstract}

Keywords: learning material, STEAM-LW approach, biotechnology, coastal area.

Abbreviations:

STEAM Science, Technology, Engineering, Art, and Mathematics

STEAM-LW Science, Technology, Engineering, Art, and Mathematics-Local Wisdom

$S B$

Student book

\section{INTRODUCTION}

Indonesia is the largest archipelagic country in the world and has a wealth of coastal resources that have not been utilized optimally for the welfare of the people. The wealth of coastal resources is a valuable development potential for the Indonesian. Unfortunately, various destructive behaviors of society have accelerated the rate of destruction of these potentials. The Government through the Ministry of National Education and the Ministry of Marine Affairs and Fisheries has placed the main backdrop of coastal community development that balances economic development with environmental carrying capacity towards sustainable coastal and small islands development. It's in line with the goals of the UNESCO program in education for sustainable development aimed at preserving the environment, economic sustainability and social welfare. This concern is based on the low quality of coastal human resources to participate in solving coastal development problems. In this program, UNESCO focuses on the development of education in secondary school students. UNESCO believes that junior high school students need to be prepared early on in order for their physiological and psychological changes to have a positive impact on the ways in accessing the lessons and have good behaviors necessary on preparing and gaining a better future. It is necessary to integrate local potential of coastal area into learning activities (UNESCO, 2017).

To establish qualified coastal human resources, it is necessary to carry out potential community-based education, for example by designing teaching materials that can improve students' thinking ability. The teaching materials are prepared by utilizing all the interesting and needed coastal potentials as they relate to the daily life of the students. By using teaching materials, students can recognize, understand, realize, and become a good problem solver. The science books used in schools today do 
not contain any potential coastal issues. This condition results in the low interest of students to learn science so as to keep students away from their goals of school. One goal of coastal school students is to have knowledge that can be used to harness the potential it has and around it in order to meet the needs of life. Student saturation arises when teaching materials and learning process used by teachers are not related to the problems of everyday student life.

One of topic in science is biotechnology. In fact, there are obstacles to teaching biotechnology topic and it causes it has received less attention in the science teaching and learning activity till now (Steele \& Aubusson, 2004; Borgerding et al., 2013). Obstacles faced by teacher in teaching biotechnology in Indonesia were lack of expertise in the content of biotechnology, less experience and suitability activity of teaching biotechnology, and lack of resources and time (Purwianingsih, 2009; Yulianti, 2016). Therefor, the availability of learning resources of biotechnology subject is important. Then, we offer the biotechnology learning material based on integrated of STEAM education and local wisdom context to tackle any problem regarding biotechnology learning in the secondary school in coastal area.

The learning material based-on STEAM-LW approach would be appropriate for increasing student's awareness and problem-solving skills by utilize biotechnology concept in context of their own local wisdom. STEAM approach is how science integrated with technology by reflective it to engineering and the arts which is all of those discipline contain mathematical elements as a mother of science (Yakman, 2008). This approach invites students to be a problem solver by integrated thinking in a particular silos field. It can become effective to bringing out any problems that related with science as a context to the integrated S-T-E-A-M activities in the classroom (Lee, 2012). Science and technology start arise and growing up in order to meet the needs of human life by any research and experiments. Those phenomena have born from our local culture (Mungmachon, 2013). Wagiran (2012) stated that "The cause of moral degradation, as follows: 1) increasingly waning native culture that has noble values and the influx of foreign culture that is not in line with our culture; 2) including a lack of support and community spirit to maintain and develop local technology and local knowledge." Subsequently, local wisdom is able to reinforce the nature of precious learning as well as drive all of students to become thoughtful to solve any problems in their daily life. So, local wisdom has a value as a context of science learning. Based on that description, value that contain of local wisdom is the art. Because art is something has beauty, uniqueness, and meaningful. Therefore local wisdom can combined precisely with STEAM in science learning.

\section{MethodologY}

The type of research was the research and development by using R2D2 (Reflective, Recursive, Design and Development) model, which consists of three phage: 1) define, 2) design and development, 3) dissemination. This model has a complete description, systematic, simple, easy to understand and involves experts' assessment (Wills, 2009; Branch \& Merrill, 2012). Stages of development on this study is presented in Figure 1.

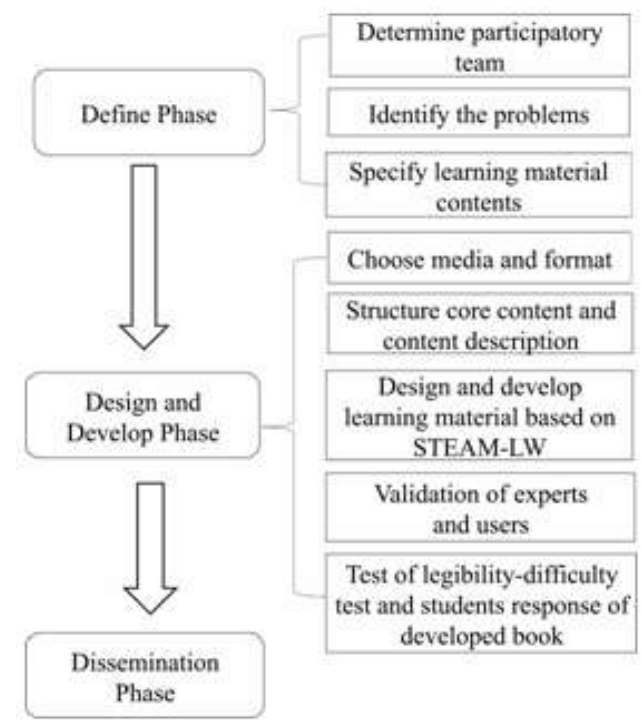

Figure1. The model of R2D2 used in this study 
The activities in the define phase were determine the participatory team, identify the problem of biotechnology learning, formulate the importance of development of learning material based on STEAM-LW (Science Technology Engineering Arts Mathematics-Local Wisdom) approach and determine the specification of learning material. The participatory team consists of reearchers, science teachers in Puger coastal area, and validators. Identify the problems of biotechnology learning was through interview and questionnaire of teachers and students. Analysis the core and basic competences of K13 revision, learning outcomes, material of biotechnology and local wisdom around Puger, Jember-Indonesia were did in order to determine and formulate developed-learning material of biotechnology.

The purposes of the design and development phase were to design the initial form of the SB and to validate it. The cognitive aspect was measured by using posttest, then affective and psychomotor aspects were measured by using observation sheet. Selected media in this study was student book with booklet format with paper size envelope C5 $(16$ x 23) $\mathrm{cm}$, designed by using Microsoft Publisher 2010 software. The preliminary design of the book in the form of integrated science book with the STEAM approach and local wisdom of the coastal area of Puger. The validation process did by three experts of biotechnology contents and media development; and three science teachers as users.

Validation results were analyzed by using percentage technique (Utomo et al., 2014), then it converted to quantitavie data with criteria in Table 1. If the results of validation achieved of $59.25 \%$ then the product can develop further. The data of legibility and difficulty test were analyzed descriptively by reviewing the result of students' evaluation. Questionnaire of student response was used to measure students' opinions on developed book. The percentage of student responses was calculated by using the formula:

\section{Percentage of students response $=\frac{A}{B} \times 100 \%$}

$\mathrm{A}=$ students that agreed

$\mathrm{B}=$ total of students

Table1. Criteria of learning material

\begin{tabular}{|l|l|l|l|}
\hline No. & Value & Quality & Decision \\
\hline 1 & $79.26-100$ & Strong valid & prototype can implement directly \\
\hline 2 & $59.26-79.25$ & Valid & $\begin{array}{l}\text { prototype can use in learning activities with } \\
\text { adding some information and need minor } \\
\text { revision }\end{array}$ \\
\hline 3 & $39.26-59.25$ & Mild valid & prototype need a few revision \\
\hline 4 & $19-39.25$ & Not valid & prototype need mayor revision \\
\hline
\end{tabular}

\section{RESULTS AND DISCUSSION}

\subsection{Define Phase}

The results of questionnaires of science teachers at SMPN 2 Puger, it is known that the problems in biotechnology subject were 1) no practical work due to limited tools and materials, 2) lack of knowledge for implementing biotechnology concept in daily life, 3) science book provide biotechnology in general and less information about biotechnology around their living area; 4) less in knowing the benefits learn biotechnology, 5) implementation of curriculum K13-revise did not accommodate local wisdom yet. The results of student questionnaire showed that only $10.25 \%$ of students knew the example of biotechnology surrounding them. Analysis of the students is also seen from the student's learning style which is the unique of each individual; there were memorize, read, understand, and varied style of $16.25 \%, 10.45 \%, 31.30 \%$ and $42 \%$, respectively. The results of student questionnaire regarding learning materials used in their study showed $43.33 \%$ using textbooks, $28.89 \%$ using the module, and $16.67 \%$ using the articles from printed and electronic media as well as handouts from the teacher. Analysis of Puger as coastal area showed that there was several local wisdom potential for integrating into learning material of biotechnology, such as fish canning, shrimp paste (terasi), shrimp sauce (petis), bioremediation and utilization of sea weed. 


\subsection{Design and Develop Phase}

The developed learning material was in form of student book of biotechnology topic. The student book used Science Technology Engineering Arts and Mathematics (STEAM) approach integrates with local wisdom, and become STEAM-LW approach. The selection of this approach was due to the ability of this approach encourage students to develop critical thinking processes deeply such as solving problems, designing experiments, conducting experiments, and reporting biotechnology on coastal area. The student book contained 20 multiple choices and five essays, projects, and biotechnology info that can induce cognitive, affective and psychomotor students. It is mentioned that instructional materials outline consists of the knowledge, skills, and attitudes that students must learn in order to achieve a defined standard competence (Kemendikbud, 2014).

The cover of students' book (SB) prototype was dominated by green-blue color (Fig 2). The prototype of SB accommodated characters of the STEAM-LW approach through several activities as follow: a) Posing Problems, it putted on the marine polution problems and students were asked to identify the main problems and find alternative solving. This activity refers to first character namely students identify science problem or issues in society from online or printed media; b) STEAM Creativity and Solely Task, it involved students to discover problems near them related to biotechnology and present solutions that used in their daily life; c) Proyek, it stimulated students to design and arrange scientific work to solve problems related to biotechnology in coastal area. it also encouraged students to collaborate in group; d) STEAM Info and Biotech Saung gave knowledge regarding biotechnology and its development; e) Sense, it correlated with students awareness on local wisdom and impact of biotechnology in coastal area. Last but not least, students' book also provided "Biotech Jokes" to create fun learning.

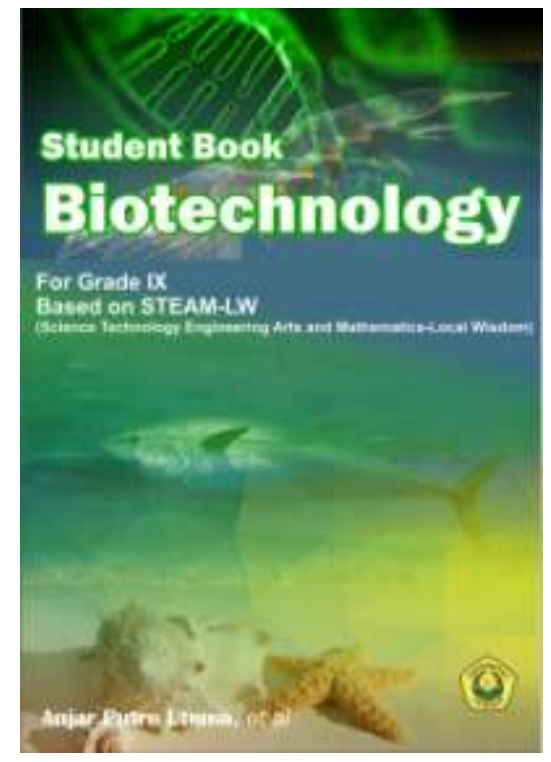

Figure2. Cover of developed-student book (SB) based on STEAM-LW approach

The prototype of SB then validated by three experts and three science teachers. The average percentage of validation results was $87.50 \%$ and it belongs to strong valid (Table 2). Then, it could use in individual test for determining the quality of SB. Individual test conducted using nine students to assess the SB according to the legality and difficulty level questionnaire, and 72 students for determining student response.

Table2. Average of validation value

\begin{tabular}{|l|l|l|l|l|l|l|l|l|}
\hline \multirow{2}{*}{ No } & \multirow{2}{*}{ Aspect } & \multicolumn{3}{|l|}{ Validator score } & $P i(\%)$ \\
\cline { 3 - 11 } & & $\mathrm{A}$ & $\mathrm{B}$ & $\mathrm{C}$ & $\mathrm{D}$ & $\mathrm{E}$ & $\mathrm{F}$ & \\
\hline 1. & Content properness & 3 & 4 & 4 & 4 & 4 & 3 & 91.67 \\
\hline 2. & Presentment & 3 & 3 & 4 & 4 & 3 & 3 & 83.33 \\
\hline 3. & Language & 4 & 4 & 3 & 3 & 3 & 4 & 87.50 \\
\hline 4. & Graphical (lay out, design) & 3 & 4 & 4 & 3 & 4 & 3 & 87.50 \\
\hline & Average & & & & & & & 87.50 \\
\hline
\end{tabular}

$A-C=$ expert validators; $D-F=$ users. 
Development of Learning Material of Biotechnology Topic Based on STEAM-LW Approach for Secondary School in Coastal Area

The result of test of legibility and difficulty level showed good or positive with value $86.61 \%$ (Table 3). This indicated that students easily understood the SB in a whole aspect. It also denoted that the SB provided exhaustive contents and ordinary language.

Table3. Result of test of legibility and difficulty level

\begin{tabular}{|c|c|c|c|c|c|}
\hline \multirow[t]{2}{*}{ No } & \multirow[t]{2}{*}{ Statement Description } & \multicolumn{2}{|c|}{ Easy } & \multicolumn{2}{|c|}{ Difficult } \\
\hline & & $\mathrm{P}$ & $\%$ & $\mathrm{P}$ & $\%$ \\
\hline \multirow[t]{5}{*}{1} & $\begin{array}{l}\text { Legibility of students' books: } \\
\text { 1. The presented material }\end{array}$ & 9 & 100 & - & - \\
\hline & 2. $\quad$ The language used & 9 & 100 & - & - \\
\hline & The presented material & 8 & 88.89 & 1 & 11.11 \\
\hline & The presented image & 9 & 100 & - & - \\
\hline & Completeness of presentation & 7 & 77.78 & 4 & 22.22 \\
\hline \multicolumn{2}{|c|}{ Average } & & 93.33 & & 6.67 \\
\hline \multirow[t]{5}{*}{2} & \multicolumn{5}{|l|}{ Components of activities that include: } \\
\hline & The lab/practicum activities & 9 & 100 & - & - \\
\hline & The STEAM-LW presented & 8 & 88.89 & 1 & 11.11 \\
\hline & The presented material & 9 & 100 & - & - \\
\hline & Completeness of presentation & 6 & 66 & 3 & 33 \\
\hline \multicolumn{2}{|c|}{ Average } & & 88.72 & & 12.28 \\
\hline 3 & Evaluation questions & 7 & 77.78 & 2 & 22.22 \\
\hline \multicolumn{2}{|c|}{ The overall average } & & 86.61 & & 14.39 \\
\hline
\end{tabular}

$P=$ number of students

The developed-SB passed validation process with strong valid quality and got high value on both of test of legibility-difficulty level and students response. It were indicated that the developed-SB can be used directly for teaching and learning process. However, a minor revision was done to accomplish the SB. Integrated STEAM-LW approach to developed-SB was worthy. This approach invites students to be a problem solver by integrated thinking in a particular silos field. By thinking in different perspective to solve any problem could stimulate students becoming aware to the peoples as well as culture. It means the student will become better in collaborative work to face any challenge in their daily life. Thus it needs a context to integrate all those silos in students learning. Because when the students study about science, so they study about all of their daily life or actual phenomena that happened in their surroundings. Therefore, it can become effective to bringing out any problems that related with science as a context to the integrated S-T-E-A-M activities in the classroom (Lee, 2012), particularly in biotechnology topic. It is strengthened by integrated local wisdom with STEAM approach in developing learning material. Students can understand easily the concept of biotechnology with incorporation of local wisdom surrounding them.

The students' response questionnaire was used to know the perception of students to developed-SB. The results showed that student positively responded to the SB whith $91.74 \%$ of agreement (Table 4).

Table4. Result of students' response

\begin{tabular}{|c|c|c|c|c|c|}
\hline \multirow[t]{2}{*}{ No } & \multirow[t]{2}{*}{ Statement Description } & \multicolumn{2}{|c|}{ Easy } & \multicolumn{2}{|c|}{ Difficult } \\
\hline & & $\mathrm{P}$ & $\%$ & $\mathrm{P}$ & $\%$ \\
\hline \multirow[t]{5}{*}{1} & $\begin{array}{l}\text { Perception about: } \\
\text { 1. The presented material }\end{array}$ & 67 & 93.05 & 5 & 6.95 \\
\hline & 2. The language used & 68 & 94.44 & 4 & 5.56 \\
\hline & 3. The presented material & 63 & 87.50 & 9 & 12.40 \\
\hline & 4. The presented image & 63 & 87.50 & 9 & 12.40 \\
\hline & 5. Completeness of presentation & 65 & 90.27 & 7 & 9.72 \\
\hline \multicolumn{2}{|c|}{ Average } & & 90.55 & & 9.45 \\
\hline \multirow[t]{3}{*}{2} & Perception about: & & & & \\
\hline & 1. The lab/practicum activities & 65 & 90.27 & 7 & 9.72 \\
\hline & 2. The STEAM-LW presented & 63 & 87.50 & 9 & 12.40 \\
\hline \multicolumn{2}{|c|}{ Average } & & 88.89 & & 11.11 \\
\hline \multirow[t]{2}{*}{3} & Perception about evaluation questions & 63 & 87.50 & 9 & 12.40 \\
\hline & & & Interest & & No \\
\hline 4 & Use STEAM-LW in the next teaching learning process & 72 & 100 & 0 & 0 \\
\hline \multicolumn{2}{|r|}{ The overall average } & & 91.74 & & 8.26 \\
\hline
\end{tabular}

$P=$ number of students

International Journal of Humanities Social Sciences and Education (IJHSSE)

Page 125 
The students' positive response represented that developed-SB based on STEAM-LW inducing more interesting and fun learning, and it was allowed contextual learning based on the student's initial knowledge as a part of society in his neighborhood. STEAM approach can integrate domain concepts, process skills, creativity, attitudes, values, implementation, and linkages between fields of study in learning science as well as emphasizing the role of science, technology, engineering, arts and mathematics in society. Integration local wisdom into STEAM aprroach can strengthen the nature of meaningful learning and encourages every student in the school to be wise, full of wisdom so as to resolve the problems of life (Santrock, 2011). Accordingly, a context of local wisdom related with biotechnology will maximize the role of STEAM in teaching and learning.

\section{CONCLUSION}

a. The process of developing a science learning material based on STEAM-LW on biotechnology subject for students in coastal area used R2D2 model generated a developed-student book that passed through validation.

b. The average percentage of six validators was $87.50 \%$ with strong valid criteria and can be used directly in learning process. While, the results of the questionnaire of legibility-difficulty level and students response were $86.61 \%$ and $91.74 \%$.

\section{ACKNOWLEDGMENT}

This study was supported by University of Jember through Program of Research Coaching 2017 (12295/UN25/LT/2017)

\section{REFERENCES}

[1] UNESCO. Indonesia UNESCO Country Programming Document 2014-2017. Jakarta: UNESCO (2017).

[2] Steele, F. and Aubusson. P. The Challenge in Teaching Biotechnology. Research in Science Education, 34, 365-387, (2004).

[3] Borgerding, L. A., Sadler, T. D., \& Koroly, M. J. Teachers ' Concerns About Biotechnology Education, $J$ Sci Educ Technol, 22:133-147 (2013).

[4] Purwianingsih, W., Rustaman. N.Y., and Redjeki, S. Identifikasi Kesulitan Pembelajaran Bioteknologi pada Guru SLTA se Jawa Barat [Identification of Difficulty in Biotechnology Learning of Senior High School Teacher in Jawa Barat Province]. Seminar Nasional Inovasi Biologi dan Pendidikan Biologi dalam Pengembangan Sumber Daya Manusia. Bandung, July $15^{\text {th }}-16^{\text {th }}$, (2009).

[5] Yulianti, E. Analisis Kesinambungan Konsep Bioteknologi Dalam Buku Pelajaran Sains [Analysis of Intercorrelation of Biotechnology Concept in Science Learning Material] , Jurnal Pendidikan Biologi, 5(1): 1-7, (2016).

[6] Yakman, G. STEAM Education: An Overview of Creating A Model of Integrative Education. Pp 1-28, (2008).

[7] Lee, G. Y. Exploring the Exemplary STEAM Education in the U.S. as a Practical Educational Framework for Korea, 32(6), 1072-1086, (2012).

[8] Mungmachon, R. (2013). Knowledge and Local Wisdom: Community Treasure. International Journal of Humanities and Social Science. 2 (13):174-181, (2012).

[9] Wagiran. Pengembangan Model Pendidikan Kearifan Lokal Dalam Mendukung Visi Pembangunan Provinsi Daerah Istimewa Yogyakarta 2020. Jurnal Penelitian dan Pengembangan [Development of Education Model of Local Wisdom in Supporting Vission of Yogyakarta]. III (3): 85-100, (2011).

[10] Willis, J. Foundations of Instructional Design: What's Worth Talking About and What is Not. In J. W. Willis (Ed.), Constructivist Instructional Design (C-ID): Foundations, Models, and Examples. Charlotte, NC: Information Age Publishing (2009).

[11]Branch, R. M., \& Merrill, M. D. Characteristics of Instructional Design Models. In R. A. Reiser \& J. V. Dempsey (Eds.), Trends and Issues in Instructional Design and Technology. Boston, MA: Pearson Education Inc. (2012).

[12]Utomo, A.P., Prihatin, J., and Pujiastuti. Pengembangan bahan ajar IPA Berbasis Pendekatan Sains Teknologi Masyarakat (STM) pada Pokok Bahasan Limbah dan Penanganannya Kelas XI Sekolah Menengah Kejuruan (SMK) [Development of Science Learning MAterial Based on STS Approach in Waste and Handling Topic Grade XI Vocational School]. Pancaran Pendidikan, 3(4): 163-174, (2014). 
[13] Kemendikbud. Permendikbud Nomor 103 Tahun 2014 Tentang Pembelajaran Pada Pendidikan Dasar dan Pendidikan Menengah [Law of Ministry of Education No. 103/2014 about Teaching and Learning in Elementary and Secondary Education]. Jakarta: Kementerian Pendidikan dan Kebudayaan RI, (2014).

[14] Santrock, J.W. Educational Psychology. New York: McGraw Hill, (2011).

\section{AUTHORS' BIOGRAPHY}

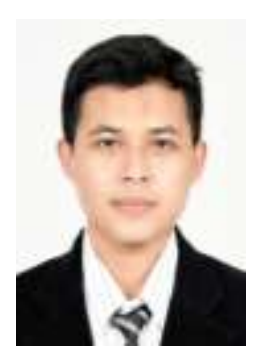

Anjar Putro Utomo, M.Ed., He was graduated from Science Education of Graduate School for IDEC (International Development and Cooperation), Hiroshima University, Japan. He concerns on science curriculum development, including STEM (STEAM) education, and higher order thinking skills.

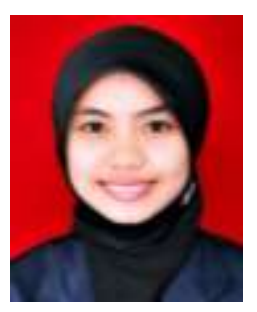

Ika Lia Novenda, M.Pd., She was graduated from Biology Education of Malang State University, Indonesia. She focuses on development of biology learning material, and environmental education.

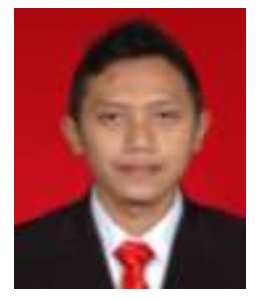

Aris Singgih Budiarso, M.Pd., He was graduated from Science Education of State University of Surabaya, Indonesia. His research interests are in hypno teaching and development of science learning material.

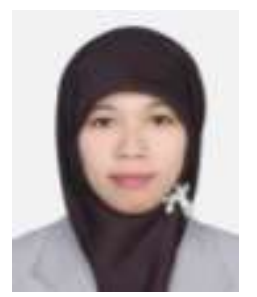

Erlia Narulita, Ph.D., She was graduated from Biotechnology Molecular of Graduate School of AdSM, Hiroshima University, Japan. She is currently a lecturer in Faculty of Teacher Training and Education, University of Jember. Her research interests not only in biotechnology aspects but also in teaching and developing curriculum of biotechnology in each education level.

Citation: Anjar Putro Utomo et al.. " Development of Learning Material of Biotechnology Topic Based on STEAM-LW Approach for Secondary School in Coastal Area." International Journal of Humanities Social Sciences and Education (IJHSSE), vol 4, no. 11, 2017, pp. 121-127. doi:http://dx.doi.org/ 10.20431/23490381.0411013 .

Copyright: (0) 2017 Authors. This is an open-access article distributed under the terms of the Creative Commons Attribution License, which permits unrestricted use, distribution, and reproduction in any medium, provided the original author and source are credited. 